\title{
Effects of albumin administration in serum liver enzymes of rats in the presence of extrahepatic biliary obstruction ${ }^{1}$
}

\author{
Efeitos da administração de albumina nos níveis séricos de enzimas hepáticas em ratos com \\ obstrução biliar extra-hepática
}

\begin{abstract}
Jorge Fernando Rebouças Lessa ${ }^{\mathrm{I}}$, Leonardo Siqueira Rangel ${ }^{\mathrm{I}}$, Nilton José de Almeida Costa Junior ${ }^{\mathrm{I}}$, Orlando Castro e Silva ${ }^{\mathrm{II}}$, Carlos Augusto Teixeira da Cruz ${ }^{\mathrm{III}}$, João Batista de Sousa ${ }^{\mathrm{III}}$

IGraduate student, School of Medicine, UnB, Brasilia-DF, Brazil. Involved with technical procedures, acquisition and interpretation of data and statistical analysis.

IIFull Professor, Head Division of Gastroenterology, Department of Surgery and Anatomy, Coordinator Liver Transplant Program, Faculty of Medicine of Ribeirao Preto, University of Sao Paulo (FMRP-USP), Ribeirao Preto-SP, Brazil. Designed the protocol, involved with interpretation of data and critical revision.

IIIPhD, Associate Professor, Surgical Clinics, School of Medicine, UnB, Brasilia-DF, Brazil. Responsible for intellectual and scientific content of the study, designed the protocol, involved with technical procedures, interpretation of data, critical revision and manuscript writing.
\end{abstract}

\begin{abstract}
PURPOSE: To study the influence of albumin on changes of liver function in the extrahepatic biliary obstruction through an experimental model in rats.

METHODS: Sixty rats were divided into four groups: Group C (Control): 6 animals. Group M (Fictitious Operation): 18 rats underwent laparotomy and handling of the bile ducts; Groups O (extrahepatic biliary obstruction) and A (Treated with $2 \%$ albumin): 18 animals in each group underwent ligation of the ductus liver; The animals in groups M, O and A were divided into three subgroups of 6 animals each to be killed in the 7, 14 and 21 days postoperative (POD). Blood was drawn for determination of total bilirubin (TB), indirect bilirubin (IB), direct bilirubin (DB), alkaline phosphatase (ALP), aspartate aminotransferase (AST) and alanine aminotransferase (ALT).
\end{abstract}

RESULTS: On POD 7, BI levels were $4.5 \mathrm{mg} / \mathrm{dl}$ in group O and $2.1 \mathrm{mg} / \mathrm{dl}$ in group A (p=0.025). On the 14th POD, the levels of PA were $1185.2 \mathrm{U} / \mathrm{l}$ in the group and $\mathrm{O} 458.3 \mathrm{U} / 1$ in group $\mathrm{A}(\mathrm{p}=0.004)$. ALT levels were $101.7 \mathrm{U} / 1$ in the group $\mathrm{O}$ and $75.7 \mathrm{U} / 1$ in group A (=0.037). On POD 21, the levels of ALP were 1069.5 U/ 1 in the group O and 468.3 U/ 1 in group A (p = 0, 004).

CONCLUSION: The administration of albumin reduced the serum levels of bilirubin in the 7th day of supplementation Key words: Cholestasis, Extrahepatic. Albumin. Enzymes. Liver. Rats.

\section{RESUMO}

OBJETIVO: Estudar a influência da albumina em alterações funcionais do fígado na obstrução biliar extra-hepática por meio de um modelo experimental desenvolvido em ratos.

MÉTODOS: 60 ratos distribuídos em quatro grupos: Grupo C (Controle): 6 animais. Grupo M (Operação Fictícia): 18 ratos submetidos à laparotomia e manuseio das vias biliares; Grupos O (Obstrução Biliar Extra-hepática) e A (Tratados com albumina a 2\%): 18 animais, em cada grupo, submetidos à ligadura do ducto hepático; Os animais dos grupos $\mathrm{M}$, $\mathrm{O}$ e A foram distribuídos em três subgrupos de 6 animais cada, para serem mortos nos $7^{\circ}, 14^{\circ}$ e $21^{\circ}$ dias pós- operatórios (DPO). Foi colhido sangue para dosagem de bilirrubina total (BT), bilirrubina indireta (BI), bilirrubina direta (BD), fosfatase alcalina (FAL), aspartato aminotransferase (AST) e alanina aminotransferase (ALT).

RESULTADOS: no $7^{\circ} \mathrm{DPO}$, os níveis de BI foram $4,5 \mathrm{mg} / \mathrm{dl}$ no grupo $\mathrm{O}$ e $2,1 \mathrm{mg} / \mathrm{dl}$ no grupo A (p=0,025). No $14^{\circ} \mathrm{DPO}$, os níveis de FAL foram 1185,2 U/1 no grupo $\mathrm{O}$ e 458,3 U/1 no grupo $\mathrm{A}(\mathrm{p}=0,004)$. Os níveis de ALT foram de 101,7 U/1 no grupo O e 75,7 U/1 no grupo A (=0,037). No $21^{\circ}$ DPO, os níveis de FAL foram de 1069,5 U/1 no grupo Oe de 468,3 U/1 no grupo A (p=0, 004).

CONCLUSÃO: a administração de albumina reduziu os níveis séricos de bilirrubina indireta no $7^{\circ}$ dia de suplementação. Descritores: Colestase Extra-Hepática. Albumina. Enzimas. Fígado. Ratos. 


\section{Introduction}

The extrahepatic biliary obstruction is associated with high rates of postoperative morbidity and mortality. Regardless of origin, it is associated with morphological and functional damage of the liver ${ }^{1,2}$, and a lower immune resistance. Hepatic changes may be evidenced by increased serum levels of direct bilirubin, resulting from canalicular backscatter, increased levels of alkaline phosphatase (ALP), gamma-glutamyltranspeptidase (gamma-GT), while levels of alanine and aspartate transaminase (AST and ALT) can be found in normal or high, all due to changes in hepatocyte membrane secondary to bile stasis ${ }^{3,4}$. In addition to the dam itself bladder, other possible mechanisms of injury include the production of free radicals ${ }^{5,6}$.

Albumin is the most abundant protein in plasma and corresponds to about $55-60 \%$ of total plasma proteins ${ }^{5,6}$. The synthesis of albumin in the liver and its secretion into the portal circulation by the same occurs soon after ${ }^{5,6}$. The colloid osmotic pressure of interstitial fluid that "bathes" the hepatocyte is the most important regulator of its production ${ }^{5}$. Their production also depends on food intake and fasting, specifically the diet deficient in protein, leads to a drastic reduction in their serum ${ }^{5}$. It is degraded by a variety of body organs ${ }^{5,6}$. Its functions are: the maintenance of colloid osmotic pressure, the carrying of substances, anticoagulation role in the metabolism of endogenous substances and interest in the maintenance of plasma $\mathrm{pH}$ and microvascular integrity ${ }^{5,6}$.

Another function performed by albumin, and of particular interest in this work is that under physiological conditions albumin plays a significant antioxidant role ${ }^{5,6}$. It inhibits the production of free radicals by polymorphonuclear leukocytes and this must be related to the abundance of sulfhydryl groups in its molecule ${ }^{5}$. As implication, hypoalbuminemic patients have a lower potential to reduce levels of free radicals ${ }^{5,6}$. Oxidative stress plays an important role in the activation of hepatic stellate cells. Antioxidants such as albumin, can prevent this activation and their subsequent role in liver fibrogenesis ${ }^{7}$.

Studies show that there is a decrease in plasma levels of albumin in rats with common bile duct ligation, although they have conflicting results ${ }^{8,9}$, with two weeks of the beginning of the experiments, probably due to increased capillary permeability and a lack of compensation by increasing its hepatic synthesis, to a decrease of the same, and also by an increase in plasma volume after four weeks of the beginning of the experiment ${ }^{10}$.

This study was designed with the aim of studying enzymatic changes in rats subjected to ligation of the extrahepatic bile duct and the influence of albumin supplementation in these animals.

\section{Methods}

This study was conducted at the Laboratory of Experimental Surgery at the University of Brasilia. The study protocol was approved by the Ethics Committee of Animal Use in Research with the University of Brasilia. All surgical procedures were performed with $2 \%$ Xylazine $(10 \mathrm{mg} / \mathrm{kg})$ and ketamine $10 \%$ $(100 \mathrm{mg} / \mathrm{kg})$ applied intramuscularly. Then, there was abdominal trichotomy, antisepsis with iodine alcohol and laparotomy.

\section{Animals and experimental design}

Sixty male Wistar rats weighing 250 to $350 \mathrm{~g}$ and 90 days of age were divided into four groups:

- Group C: 06 normal animals (control);

- Group M: 18 rats underwent laparotomy with handling of the bile ducts, but without ligation of the hepatic duct, divided into M1, M2 and M3, which will be sacrificed at 7, 14 and 21 days after the manipulation;

- Group O: 18 animals underwent laparotomy with ligation of the hepatic duct, divided into $\mathrm{O} 7, \mathrm{O} 14$ and $\mathrm{O} 21$, which will be sacrificed at 7,14 and 21 days after bile duct ligation;

- Group A: 06 animals underwent laparotomy with ligation of hepatic duct who were treated with albumin $2 \%$ (aqueous solution) ad libitum and divided into A7, A14 and A21, which will be sacrificed at 21 days and 7.14 after manipulation, for 21 days.

During the period of the study, the animals were kept in cages for 5 animals. The animals were kept at room temperature and were subjected to a light / dark cycle of 12 hours each. All animals received rat chow and water ad libitum whereas in the case of animals treated group (group A), the water contained $2 \%$ albumin.

Blood samples were collected immediately before euthanasia each rat. We made measurements of bilirubin, aminotransferases and alkaline phosphatase.

\section{Statistical analysis}

The results were analyzed with the Kruskal-Wallis followed by Dunn's method for comparison between groups, with a significance of $5 \%(\mathrm{p}<0.05)$ for all parameters.

\section{Results}

\section{Bilirubin and alkaline phosphatase}

Among the groups $\mathrm{O}$ and $\mathrm{A}$, at day 7 , there was a significant difference in levels of indirect bilirubin $(\mathrm{BI}=4.5 \mathrm{mg} / \mathrm{dl}$ in group $\mathrm{O}$ compared to $2.1 \mathrm{mg} / \mathrm{dl}$ in group $\mathrm{A}), \mathrm{p}=0.025$. In animals subjected to 14 days of supplementation with albumin there was no difference in serum levels of ALP (AL P $=1185.2 \mathrm{U} / 1$ in group $\mathrm{O}$ compared to $458.3 \mathrm{U} / 1$ in group $\mathrm{A}$ ), $\mathrm{p}=0.004$. At 21 days of supplementation was no statistical difference only for the component ALP (ALP $=1069.5 \mathrm{U} / 1$ in group $\mathrm{O}$ compared to $468.3 \mathrm{U} / 1$ in group $\mathrm{A}), \mathrm{p}=0.004$. The median values of direct and indirect bilirubin in the four groups are in Figure 1. 


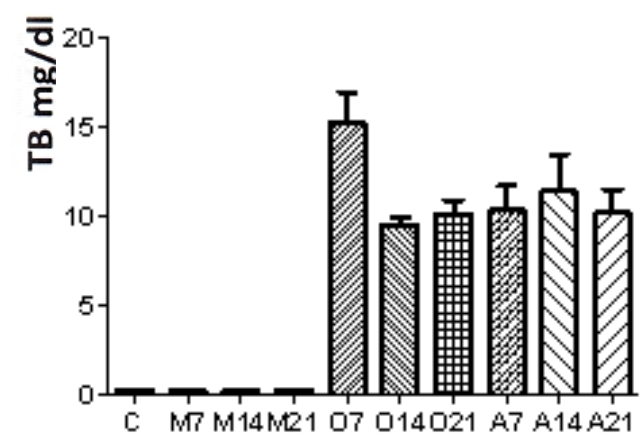

Serum level of bilirubin in all groups

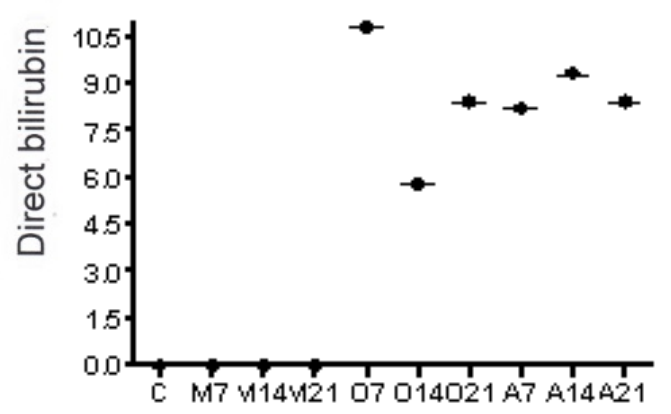

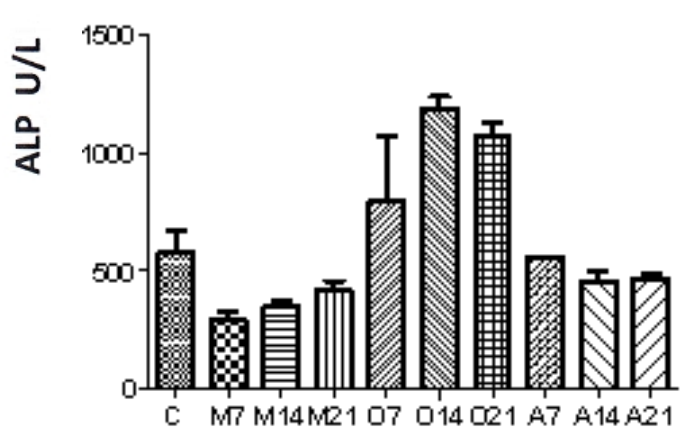

Serum level of alkaline phosphatase in all groups

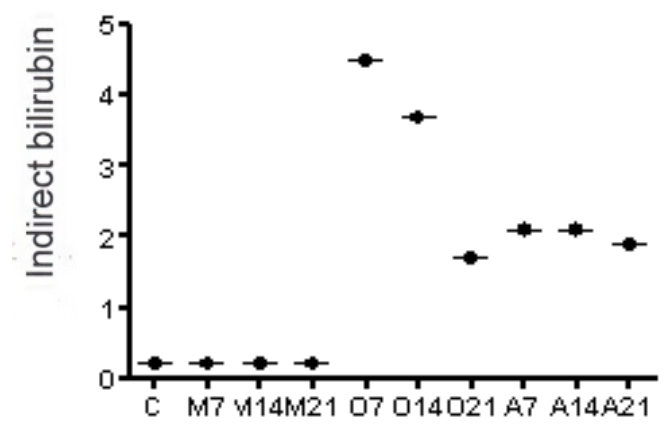

FIGURE 1 - Serum total bilirubin and alkaline phosphatase in all groups studies. Median values of serum bilirubin direct and indirect

In animals subjected to 14 days of supplementation with albumin there was difference in serum level of ALT $(\mathrm{ALT}=101.7 \mathrm{U} / \mathrm{l}$ in group $\mathrm{O}$ compared to $75.7 \mathrm{U} / \mathrm{l}$ in group $\mathrm{A})$, $p=0.037$. At 21 days of supplementation, there were no statistically significant differences between groups for any of the variables, $\mathrm{p}>0.05$ (Figure 2).

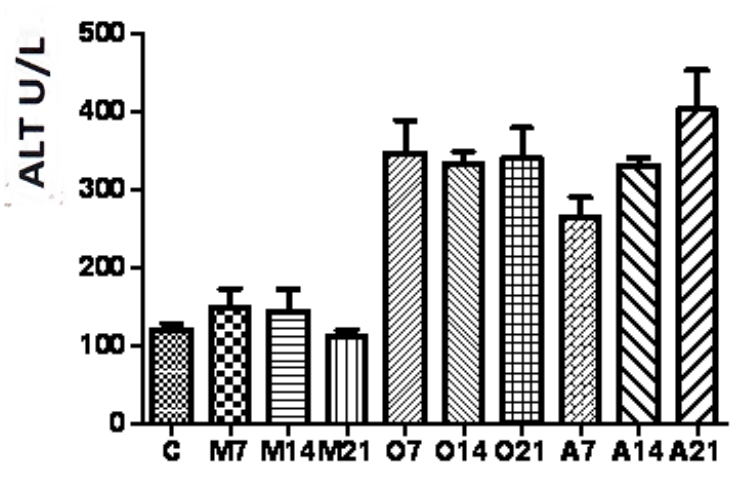

Serum level of alanine aminotransferase

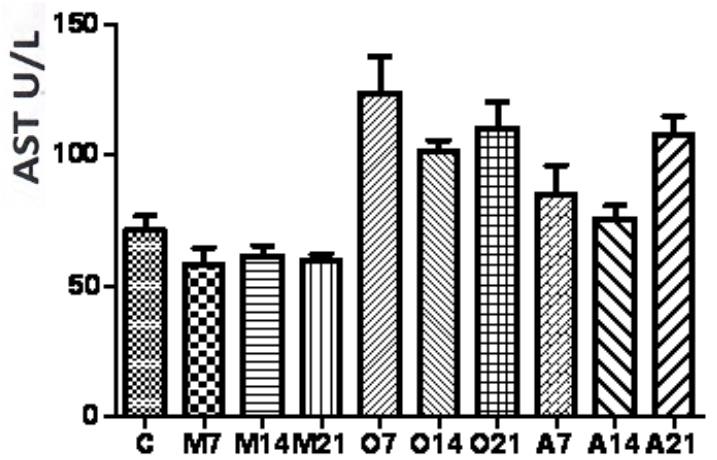

Serum level of aspartate aminotransferase

FIGURE 2 - Serum level of alanine aminotransferase and aspartate aminotransferase in all groups studies 


\section{Discussion}

The jaundice is a frequent manifestation of malignant or benign diseases of the extrahepatic bile ducts, with high morbidity and postoperative mortality ${ }^{11}$. The main reported complications are sepsis, haemorrha.ge, renal failure, hypersensitivity to endotoxin, among others ${ }^{11,12}$. Our study using the bile duct ligation as a model of extrahepatic cholestasis, both in the groups treated with albumin as the untreated perrmitiu that the biochemical changes resulting from hepatic cholestasis were evident.

When comparing the group with the Group Trashed treated with albumin, it was observed that there was a lower value of serum bilirubin serum after 7 days in the treated group, although it was not observed even after 14 and 21 days. Observing that there was no difference in the amount of direct bilirubin, albumin supplementation appears to have a protective effect on the ability of bilirubin conjugation in the short term by reducing the levels of non-conjugated fraction.

The alkaline phosphatase levels were lower in the group treated with albumin, the end of 14 and 21 days when compared to the group blocked in the absence of supplementation, suggesting a protective effect also in the canalicular secretion.

Although not expected that the levels of AST were lower in Group Albumin + blocked, since albumin has an antioxidant effect $^{5,6}$, this result was not observed at any time.

Like previous studies have demonstrated the antioxidant effect of albumin ${ }^{5,6}$ and taking into account that one of the processes involved in the development of liver injury induced by cholestasis would be to increase local release of free radicals, we raised this possibility to explain the smaller FAL indices found in our experiment.

Due to the AST found in our experiment, suggesting that enteral administration of albumin is not protective against liver damage secondary to biliary obstruction, at least at the mitochondrial level.

Finally, when comparing these same groups, the albumin-rich diet showed a protective effect in the short term, at least with respect to the permeability of the membrane hepatócioto. ALT levels tended to be lower at 7 days, although $\mathrm{p}>0.05$, while the difference was 14 days $(\mathrm{p}=0.037)$. These levels are compared to the normal range by observing the control group. These results, however, remained to the end of 21 days may be due to the antioxidant properties of albumin. However, further studies are needed to affirm this.

\section{Conclusion}

The administration of albumin to rats with experimentally induced extrahepatic biliary obstruction caused a reduction of serum bilirubin in the initial phase of treatment.

\section{References}

1. Yang R, Martin-Hawver L, Woodall C, Thomas A, Qureshi N, Morrison D, Van Way C 3rd. Administration of glutamine after hemorrhagic shock restores cellular energy, reduces cell apoptosis and damage, and increases survival. Parenter Enteral Nutr. 2007;31:94-100.

2. Jing L, Wu Q, Wang F. Glutamine induces heat-shock protein and protects against Escherichia coli lipopolysaccharide-induced vascular hyporeactivity in rats. Crit Care. 2007;11:1-7.

3. Muriel P, González P. Liver damage induced by acute cholestasis in the rat is ameliorated partially by L-arginine. Comp Biochem Physiol C. 1998;120: 421-4.

4. Castro e Silva O, Franco CFF, Souza MEJ, Picinato MAN, Zucoloto $\mathrm{S}$, Ceneviva R. Alterações hepáticas e níveis séricos de aminotransferases 24 horas após ligadura do ducto hepático em ratos. Acta Cir Bras. 1991;6:159-61.

5. Nicholson JP, Wolmarans, Park GR. The role of albumin in critical illness. Review article. Br J Anaest. 2000;85:599-610.

6. Ruot B, Béchereau F, Bayle G, Breuillé D, Obled C. The response of liver albumin synthesis to infection in rats varies with the phase of the inflammatory process. Clin Sci. 2002;102:107-14.

7. Pereira-Filho G, Ferreira C, Schwengber A, Marroni C, Zettler C, Marroni N. Role of $\mathrm{N}$-acetylcysteine on fibrosis and oxidative stress in cirrhotic rats. Arq Gastroenterol. 2008;45:156-62.

8. Tavill AS, Craigie A, Rosenoer VM. The measurement of the synthetic rate of albumin in man. Clin Sci. 1968;34:1-28.

9. Rothschild MA, Oratz M, Zimmon D, Schreiber SS, Caneghem AV. Albumin synthesis in cirrhotic subjects with ascites studied with carbonate-*4C. J Clin Invest. 1996;48: 344-50.

10. Krähenbühl S, Marti U, Grant I, Garlick PJ, Ballmer PE. Characterization of mechanisms causing hypoalbuminemia in rats with long-term bile duct ligation. J Hepatol. 1995;23:79-86.

11. Minter RM, Fan MH, Sun J, Niederbichler A, Ipaktchi K, Arbabi S, Hemmila MR, Remick DG, Wang SC, Su GL. Altered Kupffer cell function in biliary obstruction. Surgery. 2005;138:236-45.

12. Clements WDB, Diamond T, McCrory DC, Rowlands BJ. Biliary drainage in obstructive jaundice: experimental and clinical aspects. $\mathrm{Br} \mathrm{J}$ Surg. 1993;80:534-8.

\section{Correspondence:}

João Batista de Sousa

Campus Universitário Darcy Ribeiro

Prédio da Reitoria, $2^{\circ}$ pavimento, sala B2-16

70910-900 Brasília - DF Brasil

Tel.: (55 61)3307-2201

sousajb@unb.br

Conflict of interest: none

Financial source: none

${ }^{1}$ Research performed at Experimental Laboratory of Surgery, Faculty of Medicine, University Hospital of Brasilia (UnB), Brasilia, Brazil.

Presented at the XII National Congress on Experimental Surgery of the Brazilian Society for Development of Research in Surgery-SOBRADPEC, 2011 October 26-29 Ribeirao Preto-SP, Brazil. 